\title{
The Mosque as the First Political-Ideological Base in the Islamic Society
}

\author{
Abbasali Farahati \\ Faculty of Human Ecology, Public University of Kashan \\ Kashan, Esfahan, Islamic Republic of Iran \\ E-mail: abbasalifarahati@gmail.com
}

\begin{abstract}
Studying historical and archeological records shows us that most of the nations have built places for worshipping based on their own religious beliefs. Ka'abe is introduced as the first place for worshiping the Unique God of the Koran. The mosque was built by Muslims based on the Holy Prophet's order for worshiping the Unique God. Contrary to other temples or worship places during the history, mosque was not built only for worshiping and holding religious ceremonies, but for achieving many other purposes in the Islamic society too. This article is going to elaborate on these purposes.
\end{abstract}

Keywords: Mosque, Muslim, Worship, Holiness, The Holy Koran, The Holy Prophet and Ceremony

\section{Introduction}

After his migration to medina, the Prophet Muhammad (PBUH) officially founded an Islamic state. The Prophet's purpose was to establish an Islamic society and a social and ideological system for Islamic life. Naturally, forming such a state necessitated addressing new matters, founding institutions and raising new issues, such as the establishment of a social institution for gathering forces and a center for dealing with people's problems and explaining Islamic politics.

Based on this premise, selecting the mosque as the first Islamic base for Muslims to address such issues, the Prophet (PBUH) provided an opportunity for Muslims to deal with their problems and discuss their issues. Hence, upon his order, a piece of land was purchased and the construction of a mosque began. The Messenger of Allah (PBUH), along with Mohajeran and Ansar, set out to build a mosque as a fundamental element of social movement, as the result of their efforts and diligence, the construction of the mosque was completed in a short time. This mosque was plain, unadorned and extremely simple. Its floor was made of sand, its walls of brick, its pulpit of wood, and its roof from tree branches and leaves of trees (Vaghedi, 1987, pp. 231-250). Though its construction was physical, it was filled with spirituality, intimacy, cordiality, and faith and love of Allah, since it was where the Prophet (PBUH) and true believers worshipped and prayed.

Not only was the mosque used as a main place for Muslims to congregate and hold religious services, but also it was used as a community for them to spread theology, as a Jihad center for propagating Islam religion and presenting Islamic guidance as well as a political and administrative base. Thus, although the mosque was only one place, it performed several roles in the Islamic society.

\section{Methodology}

One of the useful ways of understanding the present state of a phenomenon is to obtain information about its origin, developments and factors contributing to such process. In other words, sometimes, one has to study the past for understanding the present.

If we want to understand the holiness and value of the mosque in its full sense, we have to know about the different roles that it has played in the society and the activities which have been conducted in it from the beginning, in other words, the history of the mosque.

The aim addressed in this study is to show important position of the mosque in Islam by reviewing its history. There fore the method employed in this study is historical. In this examination, more than thirty valid references have been reviewed in order to gain a full historical understanding of the position of the mosque in Islamic society. This article is going to express the roles of mosque in the five following sections:

\section{Literature review}

From the beginning of the emergence of the mosque in Islamic civilization, it has been the most significant educational, political and social institution in Islamic society. Although it has been the origin of tremendous effects and dramatic changes in various aspects of Islamic society, besides, non-Muslims scholars have virtually ignored the role of mosque in developing society, it has not been properly regarded by Muslim researchers and the scholars of Islam among the followers of other religions. Actually, no profound study on the diverse dimensions of this huge 
part of the Islamic civilization and culture has been carried out yet. Available studies, in this regard, are so scattered, limited and often transient that are not able to help us recognize the mosque and its social and practical effects in the first era of the Islamic civilization. Furthermore, most of these researches, such as the ones mentioned below, have studied the related jurisprudence rulings or architecture of some mosques. Examples of this failure of the academic world to study and understand the historical and social significance of the mosque in Islamic society follows:

Abdurraheem Ghaneemah (1986) is one of the authors who have worked on the topic. He discussed in his book, The History of Major Islamic Universities, the educational role of some great mosques in Muslim cities partly. The book, which was published in 1985 and was translated into Persian by Dr. Nurollah Kasaee, is one of the most valuable historical books in its kind about the city of Medina, Prophet Muhammad's migration center. However, what can be found in this book about the mosques are only brief mentions of them in the Prophet's era, and the book does not portray the scholastic and social role of the mosques.

Hassan Abdolwahhab has written in his book, Tareekholmasajid-al-Asareeah, about the history of architecture of some mosques, especially the ones in Egypt. Only brief references to the educational issues of the mosques can be found in this book.

Shahabaddin Ahmed Alhussayni Sahmoody (1907) has written a valuable book about the city of Medina. What can be found in this book are only brief mentions of the mosques in the Prophet's era, and no investigation on their scholastic and social roles has been carried out.

The book Arhalah, written by Mohammed bin Abdullah Tanjy bin Batootah (1929) is regarded as a famous travel journal in the history of the Islamic culture and civilization. The book's references to the educational role of mosques are dispersed and are only limited to some cities in the eastern area.

Sayyed Mahdi Kazemi Khonsari's (1956) (1956) book, Tohfat-os-Sajid fi Ahkam-el-Masjideeyah, discusses only jurisprudence rulings from the viewpoint of Shiite jurists, and has nothing to say about the educational, political and social roles of the mosque in the history of Islam. Since none of the related studies are independently concerned with the educational role of the mosque, the present paper is to take a concise but precise look at the subject.

With the point made that the historical and social significance of mosque has been largely ignored by scholarly review it is important to discuss the historical contexts. We will examine the mosque in relation to its role as worship center, education and knowledge, politics, propaganda, and social orientation.

\subsection{The Mosque as the First Worship Center}

As on Muslims' ideology, the mosque was, from the very beginning, of special value and holiness as God's house and the most beloved place. Using this sacred place necessitated observing specific rites and rules, with which Muslims had become familiar through using the Holy Koran and the Holy Prophet (PBUH)'s teachings.

The Messenger of Allah's (PBUH) instruction to hold prayers in groups in the mosque made all the Muslims come to the mosque five times a day to participate in this political-ideological ceremony and so worship Allah by making orderly lines. It is obvious that to what extent such a congregation, in which children and adults, the weak and the strong, and the poor and the rich stood side by side each other to say prayers, would eliminate hypocrisy, spite, belligerence, and pessimism and would bridge the gap between the gap between social classes and replaced them with amity, intimacy, brotherhood and equality. It was also obvious that to what extent the prayer lines made by Muslims would spark fear among hypocrites and other foes of the new religion

Thanks to such gatherings, Muslims could acquire some kinds of knowledge and also deal with many of their political, economic and social problems, these problems will be elaborated on more in the following sections. Thus, the mosque as the first worship center played a very decisive role in individual and social growth of Muslims and consequently the formation of coordinated, united, powerful and strong society in that era(Rafieddin Hamedani, 1981).

\subsection{The Mosque as the First place for Spreading Knowledge}

Islam emerged in the Arabian Peninsula when ignorance had prevailed a many regions of the world. Waves of darkness had traveled all over the world for two centuries before the emergence of Islam in 610 A.D Ali, I. Ali, I. Nahjolbalaghe (Ali, 2000). Honored to be the land of revelation, Hijaz was so involved in polytheism, superstition and traditions of ignorance that there was no sense in acquiring knowledge and raising awareness. Imam Ali (PBUH) witnessing such a condition described the existing situation like this: Allah sent his prophet when people of the world were astray and misled due to overcoming darkness and waves of sedition. Deadly passion had spoiled their wisdom and they were trapped by ignorance and anguish. Ali, I. Nahjolbalaghe (Nahjolbalaghe, Sermon, 91, p. 282,) 
Arabs of the Island of Arabia were oppressed by illiterateness and were so unfamiliar with knowledge and awareness that the Holy Koran has described them as "ommiyoon" (the illiterate or persons who are not able to read and write) (Surah 62, Verse 2). According to history, when the sun of Islam began shining upon this land, which was full of ignorance, there were only seventeen persons who were able to read and write(Belazori, 1977, p. 372). The first Koranic verses revealed to the Prophet (PBUH) verified the priority and significance of knowledge and learning: "Read in the name of thy Lord and Cherisher who created, created man out of congealed blood, Proclaim! And thy Lord is the most beautiful, who taught the use of pen, taught man that which he knew not." (Surah 96, Verse 1-5). In these verses, Allah has been referred to as "Rab". In other verses, teaching has been considered as one of the most important goals of prophet hood and one of the main duties of the Prophet (PBUH): "He who has sent amongst the unlettered an apostle from among themselves to rehearse to them His signs and to sanctify them and to instruct them in scripture and wisdom." (Surah 62, Verse 2)

Following this view, the divine religion gave priority to acquiring knowledge and called for the spreading of science as its very important goal. The Koranic verses, revealed continuously, invited Muslims to think about their environment and to use their wisdom to acquire knowledge, one of these verses is: "Will you not then understand?" (Surah 28, Verse 60) "in order that they may receive admonition" (Surah 28, Verse 46) "Will they not then think?" (Surah 6, Verse 50), "then look" (Surah 29, Verse 20). Encouraging reflection and free-thinking among Muslims, such verses fostered the spirit of knowledge acquisition and thought orientation.

The Holy Prophet (PBUH)'s words and teachings tended to the exaltation of science, scientists and scholars and the encouragement of knowledge acquisition and learning, including "acquiring knowledge is obligatory for all Muslim men and women." "Whosoever goes a way on which he seeks knowledge, Allah shall direct him to heaven, and, certainly, angles shall happily lower their wings for the pupil, and people of the earth and those of the skies and even the fish supplicate forgiveness for him, and the merit of the scholar over the worshipper is like that of full moon over other stars, and scholars are of heirs to prophets" (Sani Ameli, 1981, p. 25) and "Seek knowledge even if it is in China (farthest part of the world)."_(Albokhari, 1980, p. 25). Thanks to the new conditions provided by Islam at the age of ignorance, the significance of knowledge and awareness fostering became known to all followers of this religion and became a religious and indispensable obligation. Due to the efforts made by the school of Islam to increase people' awareness, mosques which had already been the main places for worshipping were used as the first base for learning knowledge and the Holy Koran was considered as the first book and text for teaching the Muslims.

The Holy Prophet (PBUH) specified the great mosque located in Medina as the main base for spreading Islamic knowledge and learning and also specified himself as the first teacher of this Islamic academy. In this way, he made the Arabs gather around him for acquiring knowledge. The Holy Prophet began educating the Muslims through the verses of the Holy Koran and his instructive saying, examples follows:

Bokhari wrote in his book entitled Sahih the following: "One day as the Holy Prophet (PBUH) sat along with his followers at the mosque, three people entered there. Two of them went to the Prophet (PBUH) and stood before him. One of them found a place among the followers and sat there. The other one stood behind the followers. The third person, turning his face from those people, left the mosque. The prophet (PBUH) said "shall I tell you about the three persons?, One of them sought to God and God accepted him so he sat among the followers, the second one became ashamed so God became ashamed of him, and the third one turned away, therefore God turned his face from him too." (Albokhari, 1980, p. 15).

In addition, the Prophet (PBUH) entrusted a man named Abdullah Ibn Saeed with the task of instructing reading and writing to Muslims in order to develop these two skills among them (Ezzati, 1987). After a while some people of Medina became literate and so they became able to read and write the Holy Koran. After the Badr war, the Holy Prophet (PBUH) announced that literate captives of war could gain their freedom by instructing reading and writing to ten children(Alghalghashandi, 1917). Thus, since the ability to read and write was considered holy and divine the mosques were used as the first instruction centers.

The Medina Mosque and other mosques at that time were officially regarded as centers for teaching and learning the Holy Koran and discussing and dealing with religious issues (Monabbah, 1985, p. 6). In order to learn the Holy Koran and Islamic jurisprudence, Muslims attended at the sessions on scientific issues formed by great disciples of the Holy Prophet (PBUH). Disciples like Imam Ali (PBUH), Ziad Ibn Sabit, Maadh Ibn Jabal, Abi Ibn Ka'ab eagerly after fulfilling their religious obligations or on other occasions at the mosque led sessions. Sometimes, the messenger of Allah (PBUH) himself attended these sessions to encourage and exalt the great disciples and spreading knowledge. Ibn Abdulber quotes based on one of disciples of the Messenger of Allah (PBUH) named Abi Alqamra that we made some circles at the Mosque of the Holy Prophet. When he came out of his chamber, he looked at the 
circles inside the mosque, then he sat beside the followers of the Koran and said: "I have been ordered to this gathering."(Ibn Abdolber Alghortobi, n.d, p. 1917).

It is also said that on one day, the Holy Prophet entered the mosque and saw two gatherings, one of them was discussing about the science of gnosis and the other one were praying. The Holy Prophet said "These two groups are making efforts to achieve goodness and salvation since the former group are acquiring knowledge and are going to teach it to others and the latter one is calling upon Allah. In my opinion, the latter one is better. I have also been sent for teaching the messages of Islam to people." Then the Holy Prophet sat beside them (Ameli, 1981, p. 26).

As previously noted, the holding of the sessions on scientific issues was not restricted to only the Prophet (PBUH)'s Mosque, they were held at other mosques of Medina too. According to Makhool " ten disciples of the Holy Prophet (PBUH) told me that they had been studying at Qoba mosque; leaving the mosque, the Holy Prophet (PBUH) said: 'Learn what you want to know, and Allah will not reward you unless you apply and practice what you have learned." (Zarghani, (1025, p. 314).

It is worthwhile to note that educational activities at the mosque were not limited to only teaching the Koran and religious matters, but literary gatherings were also formed at the mosque also at that time. Poets read their poems before the Holy Prophet (PBUH) in the mosque and they were sometimes awarded by him. Ka'ab Ibn Zohair read his famous ode "Soad (poet's beloved one) went away and my heart aches with longing for her." In the Holy Prophet (PBUH)'s presence at the Prophet's Mosque and received a prize from him(Rafieddin Hamedani, 1981, p. 952). As it is also said; the Holy Prophet (PBUH) ordered to place a pulpit for Hisn Ibn Sabit at the mosque and he read his poems from the pulpit (Ibn Sa'ad Vaghedi, 1957, p. 745) Except the mentioned narrations, there are many other accounts in the historical documents that confirm the presence of he literary gatherings and activities at mosques at the time of the Prophet (PBUH), an example follows here:

Vaqad Tamim told once up on time, while he was with the Holy Prophet (PBUH) at the Medina Mosque, Atarod Ibn Hajib, who was the leader of Bani Tamim tribe, along with his folk, including Aqra Ibn Habis and Zearqan Ibn Badr arrived the mosque and came to the prophet. They said "Muhammad! We have come here to tell you about our prides and works." The Holy Prophet (PBUH) asked them to do so. Atarod Ibn Hajib, their leader and lecturer, stood and read "Praise to Allah....." Having read this, he sat down. Then the Prophet asked Sabit Ibn Qais to stand up and respond to the lecturer. He stood and recited his poem: "Praise to Allah, whose creations are the earth and the skies, in which He decreed his matter, His throne doth extend His creation." After he finished reading, another poet stood and recited his poem. The prophet sent someone after Hisan Ibn Sabit, then he came to the mosque and read some poems (Rafieddin Hamedani, 1981, p. 1092). On that day, after Hisan had ended his poem, the Holy Prophet (PBUH) said: "May Allah bless Hisan with the Holy Spirit as long as he defends the Messenger of Allah." That day, the Prophet (PBUH) and Muslims delighted in Sabit's lecture and Hisan's poem (Samhoodi, 1907, p. 167). Thus, the mosque as the first scientific base in the newly established Islamic society began its mission of disseminating knowledge and spreading Islamic culture. With the passage of time, more scientific activities were done at the mosque, so that it was known as the most important center of scientific activities in the Islamic world by the fourth century. (Metz, 1967).

\subsection{Mosque as the First Political Center in the Islamic Society}

Since there are no gaps between authorities and different classes of people in the

Islamic society, Muslims can monitor the government' activities and declare their opinions about political issues freely. After founding the new Islamic system in Medina, the Prophet introduced the mosque as a public center for Muslims to gather and do their religious duties there. Mosque gave such an authority to people that they could take significant roles in government's decisions.

At the mosque, the Prophet (PBUH) put Islam's political principles to

Practice, particularly those about which, he knew, Muslims had useful ideas and experiences. History tells us that the Prophet consulted his disciples about taking good positions in the Badr war (the first military war between Muslims and polytheists of Mecca in a place called Badr which was, geographically, between Mecca and Medina after the Holy Prophet's migration to Medina) in a mosque in the suburbs of Medina called Arqotayebeh. (Samhoodi, 1907, p. 167). In addition, he paid attention to Muslims' opinions about going to war in Ohod in the Mosque of Medina. (Ibn Hesham Alasaferi, 1935, p. 67).

The Holy Prophet (PBUH) provided mental and social preparation of most of wars in Mosque. He mobilized Muslims by his effective speech for war in the mosque and dispatched them to the battlefield. According to Ibn Hesham, for participating in Ohod war, Prophet (PBUH) and his disciples moved from the mosque to the battlefield on Friday after saying prayers. (Ibn Hesham Alasaferi, 1935, p. 67). 
Vagqedi writes in his Maqadhi: "the prophet (PBUH) entered the mosque to say two-Rak'at (unite of prayers consisting of three posturs: standing, genuflection and prostration) prayer. he had serious wounds (from Ohod war) and he wanted to go to Hamra Al-Asad war. People had gathered and even those from upper Medina came to the mosque after they had heard the order. Then, the Prophet ordered that they bring his horse in front of the mosque. He wore armor and armet so that only his eyes could be seen." (Vaghedi, 1987, p. 247).

Thus, mosque as Jihad and movement base played a major role at that time. The messengers and chiefs of tribes who came to Medina for negotiating with the Holy Prophet (PBUH) met him at the mosque (Ibrahim Hasan, p. 102). His meeting with the representatives of the Saqif tribe at the Medina Mosque was among important events of the Madaniah age, on which historians have elaborated. As Vaghedi says:

"The Holy Prophet (PBUH) ordered that they make three of shade using palm tree leaves and branches in the mosque. He heard his disciples' reciting of the Holy Koran at nights and saw their nightly worship. At the time of obligatory prayers, he saw lines of Muslims standing for prayers. The representatives stayed there to reply to the Messenger of Allah (PBUH)'s invitation(Vaghedi, 1987, p. 733).

Judicial activities, resolving disputes, inflicting Islamic punishment on offenders and imprisoning and chastising them were made in the mosque. As decreed by the Holy Koran:

"so judge between them by what Allah hatch revealed" (Surah 5, Verse 53) and also "But no by thy Lord they can have no faith until they make three judges in all disputes between them and find in bowls no resistance against thy decisions" (Surah 5, Vesre 53). The Holy Prophet himself judged about Muslims problems and solved them.

(Alghorashi \& Ahmad, 1976, p. 15). If a criminal had been convicted to jail or Islamic punishment, these sentences would be executed at the mosque. As well, captives were brought to the mosque and bound to one of pillars of it, so that the people (PBUH) could sentence them (Albokhari, 1980, p. 123). Hence, the mosque at that time was a place of administration of justice, a place in which all judicial affairs were conducted.

It should be pointed out that the mosque was still active in terms of political matters in later eras, and most political issues of that day such as introducing the Caliph, swearing allegiance to him, unseating and assigning governors and other state authorities, consultative meetings, encouraging Muslims to Jihad against the infidels, dispatching forces to the battlefield and also judicial matters such as hearing, apprehension, imprisonment and execution of Islamic punishment were all done in the mosque(Albokhari, 1980) (Albokhari, 1980, p. 81 \& Mofid, n.d, p. 84). Thus, the mosque, from the beginning of its political life at the time of the Holy Prophet (PBUH) until early Abbasi era was regarded as the center of all political activities of Islamic global movement.

\subsection{Mosque as the First Propagation Center}

Undoubtedly, the prophet's (PBUH) motivation for migration to Medina, as witnessed by history, was to find a suitable and peaceful environment and to access necessary facilities for propagating and spreading Islam. Therefore, after the messenger of Allah (PBUH) had settled in Medina, the mosque which was the only public center for making relations among members of Islamic society was used as the main base for Muslims to propagate Islam.

The Holy Prophet (PBUH) propagated Islamic culture through the mosque in light of Islam's divine teachings and through lecturing, preaching, guiding, and holding Friday prayers, speeches and other things, and displayed the magnificence of the religion by holding Friday and congregation glorious prayers and forming scientific circles. Muslims and followers of the Holy Prophet (PBUH) performed their Islamic duties very impresssingly. For instance some of the disciples such as Abdullah Ibn Masud, Zaid Ibn Sabit, Abi Ibn Ka'ab recited Koranic verses so sweetly that the groups who had recently arrived in Medina as the envoys of Saqif tribe were impressed strikingly. These envoys had come to Medina to negotiate with the prophet (PBUH) and they became surprised by seeing Muslims' congested lines for doing Islamic obligations like saying prayers. (Vaghedi, 1987, p. 734). Thus, as a result of Muslims' efforts for propagating Islam at the mosque of the Prophet, people gained enough information for accepting Islam. Therefore whenever a representative of one of the tribes came to Medina for gaining information about the new religion, he immediately accepted Islam and followed it.

In addition, the Mosque of the Prophet (PBUH) in Medina resembled a big propagation center in which the Messenger of Allah taught missionaries through his instructive guidance. After hey had become knowledgeable about the Koran and Islamic jurisprudence, the Holy Prophet dispatched them to different parts of Arabian Peninsula to enlighten the people. His focus was to bring the people of those territories out of the darkness of ignorance and polytheism as well as call them to the bosom of Islam. It was mainly through propagation of the enlightened graduates of the revelation and prophethood that not only did Islam spread to all parts of Arabia but also it pervaded a large part of the world shortly after the messenger of Allah (PBUH)'s demise. It was through this cultural and ideological victory that mosques, pulpits, Islamic jurisprudence classes, Hadith (the sayings of the Holy Prophet and 
members of this household), literature, speech, interpretation, ethics and other Islamic studies were manifested by Islam. In this way, as the result of scientific and cultural waves, Muslim missionaries created in those parts in early Islamic centuries, mosques turned into scientific and Islamic culture propagation centers in all big cities and even villages.

\subsection{The Mosque as a Social Service Center}

From the very beginning, the mosque played a major role in providing social relief and services as well as persuading scientific activities. A group of Muslims lived in a mosque in Medina and so enjoyed the Holy Prophet and Muslim community aid. Consisting of 400 followers of the Prophet, the group had settled in the mosque at the Prophet's order. They learned the Koran, fasted and went to war while settling there (Ghonaymeh, 1986, p. 340).

Ibn Sa'ad writes in Tabaqat: "At nights, the messenger of Allah called the Soffah people and sent a number of them to the house of one of the Ansars, and took some others to his own house and entertained them (Ibn Sa'ad Vaghedi, 1957, p. 225). The mosque was a place where medical and treatment services were provided for the wounded warriors in the mosque and treated the wounded men there (Vaghedi, 1987, p. 180). In addition, In the Khandagh war, and pursuant to the Holy Prophet's order, a tent was erected in the mosque and bedridden Sa'ad Ibn Ibadeh who had been wounded in was cared for and visited by people there and people came to visit him(Albokhari, 1980, p. 123). Ahmad Isa (Bek) in his book on hospitals, tells that the first hospitals in Islam were the tents which the Prophet (PBUH) erected during Khandagh war in the Medina Mosque for treating the wounded men, and entrusted to a woman called Rafideh with looking after them (Ghonaymeh, 1986, p. 168). Thus, it could be said that the mosque served as today's hospital at that time. In end, among other social services in the mosque also was helping the Muslim community financially then (Ibn Taghtaghi, 1931, p. 112). Whenever Medina possessed some wealth, it was brought to the Mosque. This custom was maintained and followed by Aboobakr too (Ibn Taghtaghi, 1931, p. 112).

\section{Conclusion}

In accordance with the history of Islam this article uncovers that mosques were not only built for worshiping the Unique God, but they have played other significant roles such as guiding and educating people, judging about their disputes, dealing with their problems, participating in the current government's decisions and social community in general throughout history as well. Therefore historical analysis uncovered and set forth in this article allows us to conclude that the institution of mosque in Islam is very foundational, broad and instrumental to society. It may be concluded that the most important organization in Islamic society is the mosque, if it is introduced appropriately to Muslims.

\section{Recommendations}

The future research on the mosque may focus on the following topics:

1. Examining the architecture of mosques during the history.

2. Investigating the classification of mosques.

3. Studying the main differences between the mosque and other places of worship.

\section{References}

Albokhari, A. A. I. M. I. E. (1980). Aljameolsahih [Comprehensive confirmation]. Beiroot: Dare Ehyael Torasel Arabi.

Alghalghashandi, A. A. (1917). Sobhol Asha Fi Sena'atol Ensha [Showing the right way through writing (this book)]. Ghahere: Maktabat MAshkatol Eslamiyyat.

Alghorashi, M. I., \& Ahmad, M. I. (1976). Ma'alemol Ghorbat Fi Ahkamel Hesbah. Egypt: Alheyatol Mesriyah Alammat Lelketab.

Ameli. (1981). Iran.

Batootah, M. b. A. T. b. (1929). famous travel journal in the history of the Islamic culture and civilization.

Belazori, A. I. Y. (1977). Fotuhol Boldan [The conquest of towns]. Beiroot: Darol Kotob Alelmiye.

Ezzati, A. (1987). Amoozesh va Parvaresh Eslami [Islamic education]. Tehran: Be'asat publication.

Ghonaymeh, A. (1986). Tarikh Daneshgahhaye Bozorg Eslmii [The history of Islamic great universities]. Tehran: Yazdan publication.

Ibn Abdolber Alghortobi, A. O. Y. (n.d). Alestiab Fi Marefatel Ashab [Searching and inquiry for getting knowledge about the followers of The Holy Prophet]. Ghahere: Maktabol Nehzat. 
Ibn Hesham Alasaferi, A. M. A. (1935). Alsayyeratol Nabovviyat [The Holy Prophet's characters]. Egypt.

Ibn Sa'ad Vaghedi, M. I. S. a. (1957). Alttabaghatekobra [Comprehensive stages]. Beiroot: Darolkotob Alelmiye. Ibn Taghtaghi, M. I. A. I. T. (1931). Tarikh Fakhri. [Fakhri's history]. Tehran: Bongah Tarjome va Nashr Ketab. Ibrahim Hasan, H. Tarikhel Eslamel Siyasi .[The history of political Islam].

Khonsari's, S. M. K. (1956). Tohfat-os-Sajid fi Ahkam-el-Masjideeyah. Iran.

Metz, A. (1967). The Islamic Civilization in the Fourth Century of the Hegira. Beiroot: Darol Ketabol Arrabiyyat. Monabbah. (1985). Monabbah.

Rafieddin Hamedani, I. I. M. (1981). Sirate Rasul Allah (PUH) [Rasul Allah's (PUH) character]. Tehran: Bonyad Farhang Iran publication.

Samhoodi, S. A. (1907). Vafaol Vafa Beakhbar Darel Mostafa [The geographical history of Medina]. Egypt: Matbaatol Adab.

Sani Ameli, Z. (1981). Monitol Morid [Knowledge followers' desire]. Qom: Majmaozzakhaerel Eslamiyyat. Vaghedi, M. I. O. (1987). Almaghazi [wars]. Tehran: Markaze Daneshgahi publication center.

Zarghani, M. A. (1025). The ways to acquire gnosticism. Beiroot: Darol Kotob Alarabiyat. 